\title{
Airborne spreading and deposition of de-icing salt - a case study
}

Reprint from The Science of the Total Environment 235, 1999 , pp. 161-168

Göran Blomqvist, VTI and

Eva-Lotta Johansson, Royal Institute of Technology, KTH Haninge

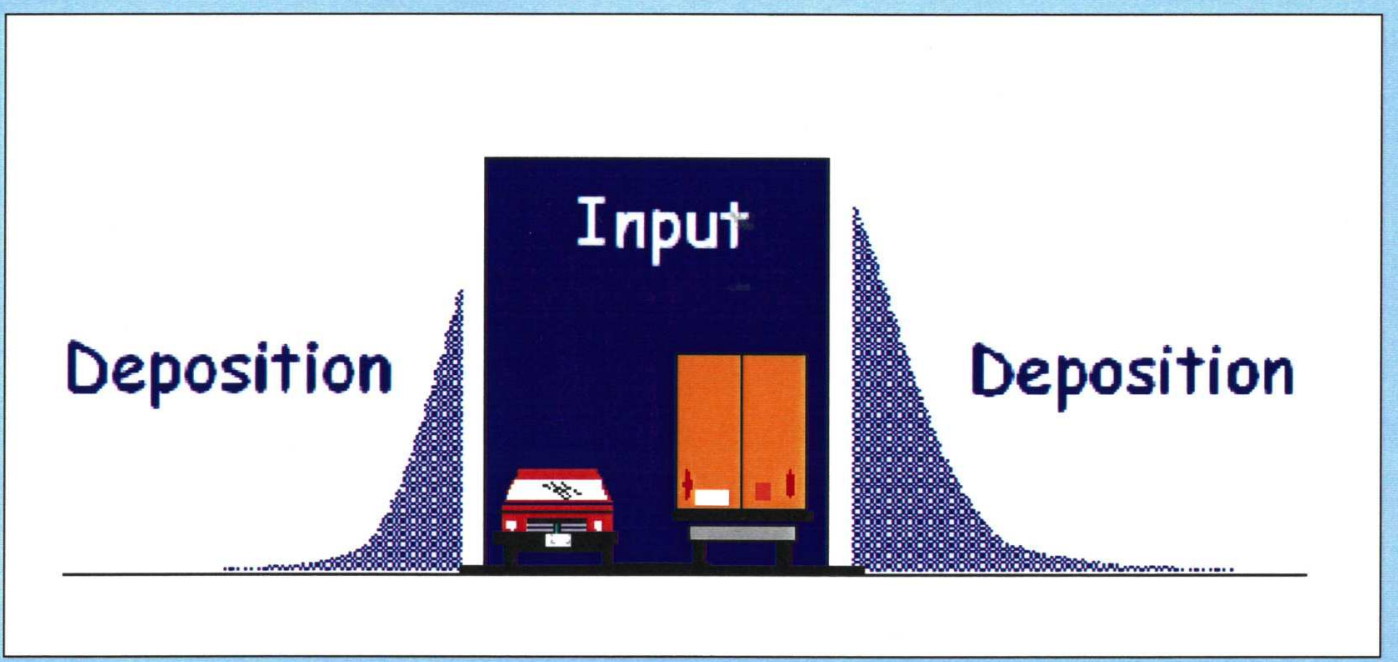

dis 


\section{VTI särtryck $331 \cdot 1999$}

\section{Airborne spreading and deposition of de-icing salt - a case study}

Reprint from The Science of the Total Environment 235, 1999, pp. 161-168

Göran Blomqvist, VTI and Eva-Lotta Johansson, Royal Institute of Technology, KTH Haninge 


\title{
Airborne spreading and deposition of de-icing salt - a case study
}

\author{
Göran Blomqvist ${ }^{\mathrm{a}, *}$, Eva-Lotta Johansson ${ }^{\mathrm{b}}$ \\ ${ }^{a}$ Swedish National Road and Transport Research Institute, SE-581 95 Linköping, Sweden \\ ${ }^{\mathrm{b}}$ Royal Institute of Technology, KTH Haninge, Marinens väg 30, SE-136 40 Haninge, Sweden
}

\begin{abstract}
In this study it was concluded that between 20 and $63 \%$ of the de-icing salt applied on the road was transported by air and deposited on the ground $2-40 \mathrm{~m}$ from the road. The reason for the higher percentages is suggested to be intense snowfall, which leads to more splash generation and ploughing. Ninety percent or more of the total deposition occurs within $20 \mathrm{~m}$ at all transects. For all periods and both localities the deposition was greater on the east side of the road, which reflects the prevailing westerly winds in relation to the de-icing action occasions. (c) 1999 Elsevier Science B.V. All rights reserved.
\end{abstract}

Keywords: De-icing salt; Airborne spreading; Deposition; Budget; Road weather information system (RWIS)

\section{Introduction}

Snow and ice control can be made with mechanical or chemical methods. In Sweden the de-icing agent almost exclusively used is sodium chloride due to its low price. Sodium chloride is spread mechanically to the roads either as dry

\footnotetext{
*Corresponding author. Tel.: +46-13-20-41-71; fax: +4613-20-40-30.

E-mail address: goran.blomqvist@vti.se (G. Blomqvist)
}

salt, moistured salt or in solution, depending on the state of the road.

The de-icing salt applied on the road surface can be spread to the roadside environment through different transport mechanisms such as runoff, infiltration, airborne spreading (splash, spray, particulates) and ploughing (Fig. 1). Salt has been found to be transported by air several hundreds of metres from the road above open ground (Kelsey and Hootman, 1992), but at forested sites the vegetation is filtering the air leading to higher deposited amounts on the 


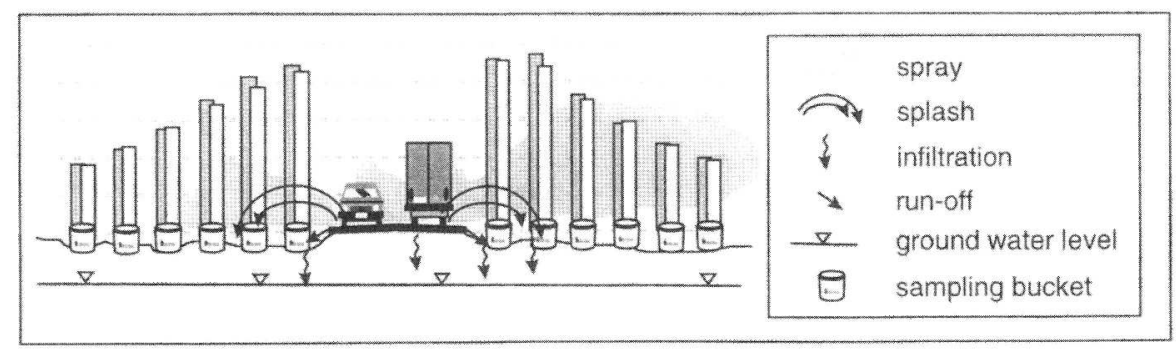

Fig. 1. Conceptual model of transport mechanisms and sampling method.

ground under the vegetation (Hautala et al., 1995). Under certain conditions the vegetation is likely to be damaged by such salt deposition. Deposition on the ground might also lead to effects such as alteration of soil structure and possible infiltration and percolation to groundwater (Bäckman and Folkeson, 1995).

The deposition of de-icing salt next to roads has been assessed by e.g. collecting the deposition in containers (Karlqvist, 1974; Kelsey and Hootman, 1992; Pedersen and Fostad, 1996), by snowsampling (Simini and Leone, 1986; McBean and Al-Nassri 1987; Hautala et al., 1995; Eliasson, 1996) by soil sampling (Hofstra et al., 1979; Dragsted, 1980; Persson and Røyseland, 1981; Jones et al., 1986; Rutter and Thompson, 1986; Pilon and Howard, 1987; Bäckman and Folkeson, 1995; Pedersen and Fostad, 1996; Røhr, 1996; Bäckman, 1997) or by analysing salt concentration in vegetation (Hofstra and Hall, 1971; Bäckman and Folkeson, 1995; Pedersen and Fostad, 1996).

Budgets have been made for lead and PAHs based on vehicular emissions (Harrison et al., 1985; Hewitt and Rashed, 1990).

In studies of airborne de-icing salt migration McBean and Al-Nassri (1987) concluded that $90 \%$ of the deposited salt was found within $13 \mathrm{~m}$. However, they assumed that the maximum possible distance to which the salt will migrate is $30 \mathrm{~m}$ from the edge of the road shoulder, and in their investigation the deposition is not related to the amount of salt applied on the road. Pedersen and Fostad (1996) showed that 10-25\% of the applied salt was spread through the air and that most of this salt was deposited within $8 \mathrm{~m}$ of the roadway. The samples were taken $2-16$ or $2-20 \mathrm{~m}$ from the edge of the road and the budget is calculated from the total amount of road salt applied during that season.

The aims of the present study are to quantify the amount of de-icing salt transported by air (the remainder will be transported as runoff or infiltrate in the road construction) and deposited on the ground adjacent to the road and relate that to the total amount of salt applied on the road. During the deposition periods, meteorological parameters such as temperature, wind direction and speed, and precipitation amount and type were registered in order to investigate their importance for the deposition pattern.

\section{Materials and methods}

The Swedish National Road administration has developed a system for supervision of the local weather at some major Swedish roads. The Road Weather Information System (RWIS) measures, e.g. temperature in air and at road surface, wind velocity and direction and precipitation type and amount. In order to investigate the meteorological factors the two field investigations were located at RWIS stations.

One of the localities chosen for field studies was Älgviken, $50 \mathrm{~km}$ south of Stockholm (Fig. 2) at National Road 73 which has an average daily traffic of 8000 vehicles and a speed limit of $90 \mathrm{~km}$ $\mathrm{h}^{-1}$. At the locality the road runs in a north-south orientation with a ploughed field west of the road and a meadow east of the road. On the west side there is a ditch at about $4 \mathrm{~m}$ from the edge line, and on the east side the ditch is at a distance of 


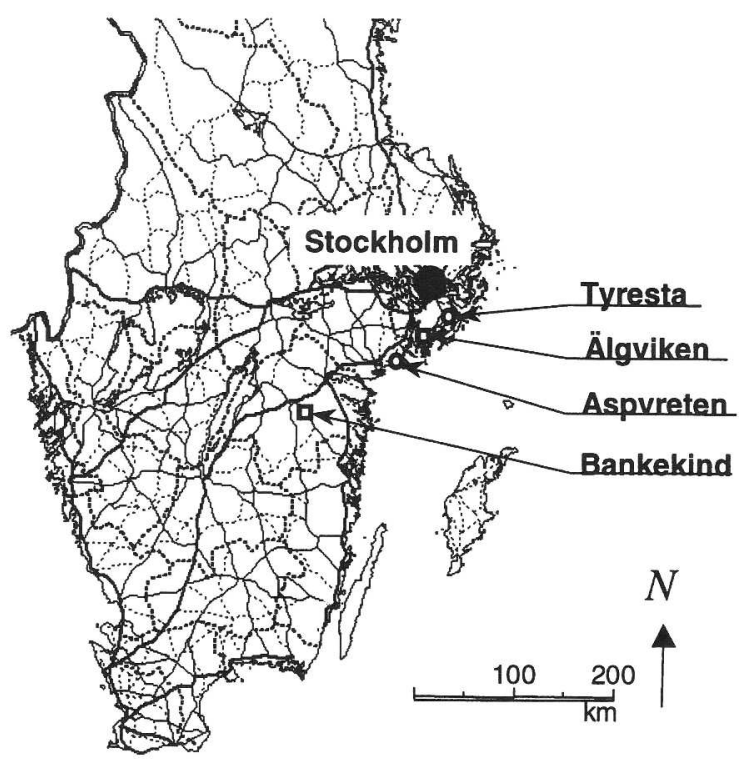

Fig. 2. Map of the two sampling localities (squares) and precipitation stations (circles).

about $6 \mathrm{~m}$ from the road. The Baltic Sea is about $2 \mathrm{~km}$ east of the road.

The other locality was Bankekind, $10 \mathrm{~km}$ southeast of Linköping (Fig. 2) at the National Road 35. The road has an average daily traffic of 5500 vehicles, a speed limit of $90 \mathrm{~km} \mathrm{~h}^{-1}$ and runs in a NW-SE orientation. West of the road there is a meadow and east of the road there is a harvested but not ploughed farmland. There are ditches on both sides of the road at $4 \mathrm{~m}$ from the edge line.

The deposition was collected in 2.7-1 polyethy- lene buckets (175 $\mathrm{mm}$ diameter). The containers were placed in double transects $2 \mathrm{~m}$ apart at the distances of $2,4,6,10,20$, and $40 \mathrm{~m}$ from the edge line of the road on both sides of the road. At Älgviken the containers were collected and replaced once a week (i.e. 7-15 February, 15-22 February, and 22 February-1 March 1997, Fig. 3). At Bankekind the containers were collected every two weeks (i.e. 6-19 February, and 19 February-3 March 1997, Fig. 3) except from a $400 \mathrm{~m}$ profile with containers placed at $2,4,6,10,20,40,60$, 100,200 and $400 \mathrm{~m}$, where the containers were collected after 4 weeks (i.e. 6 February-3 March 1997).

Both roads were de-iced with $\mathrm{NaCl}$ during the sampling period. Data about applied amount of salt were available at the local road maintenance stations. In this case the applied amount of salt was given in $\mathrm{g} \cdot \mathrm{m}^{-2}$ applied road surface or in tonnes per $\mathrm{km}$ road length. The amounts were recalculated to amounts of salt in $\mathrm{g} \cdot \mathrm{m}^{-1}$ in order to compare the amounts applied on the road to the amounts deposited at different distances. Furthermore, at each locality a road weather information device registered the amount and type of precipitation, speed and direction of wind and temperatures in the air and at the road surface every half-hour. According to Ericsson (1995) there is a rapid decrease in concentration of de-icing salt on the road within the first hours after a de-icing action has taken place. Hence, the wind direction and speed was considered only

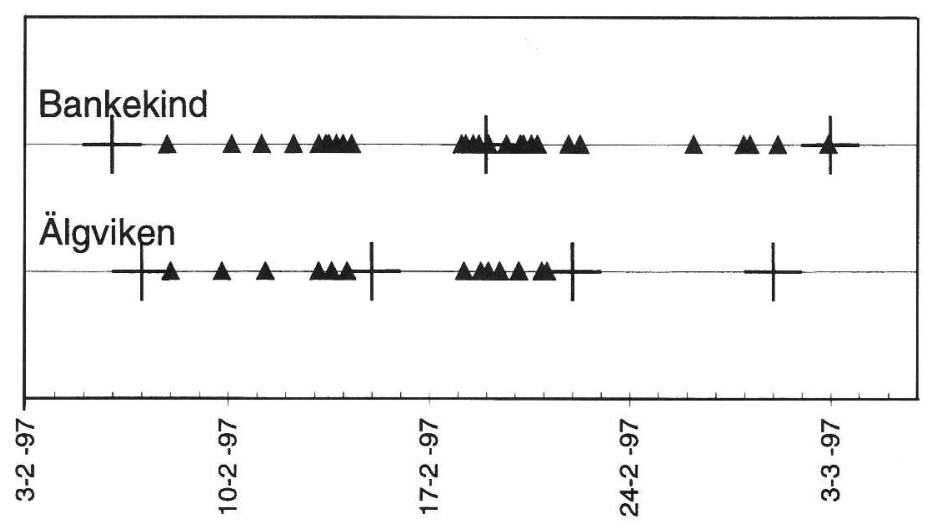

Fig. 3. Sampling periods and de-icing action occasions at each locality. 

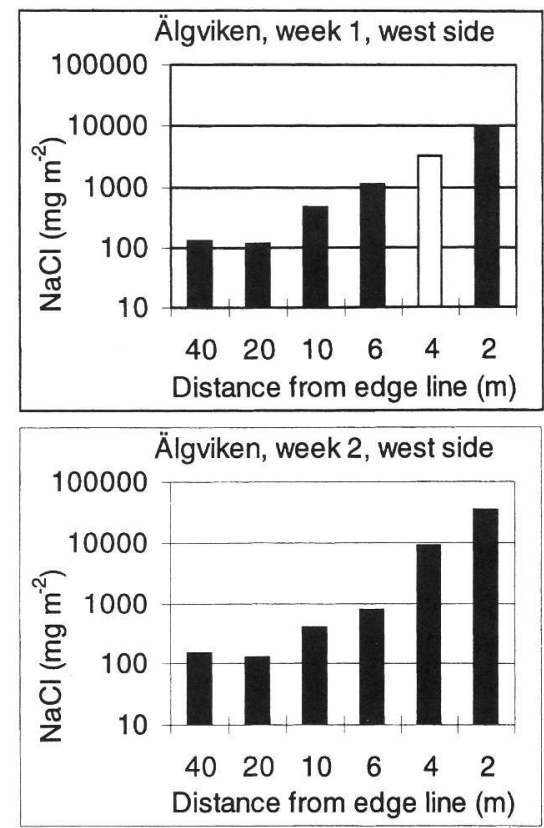

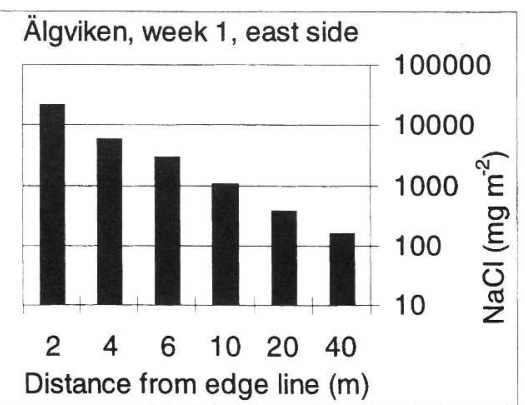

Älgviken, week 2, east side

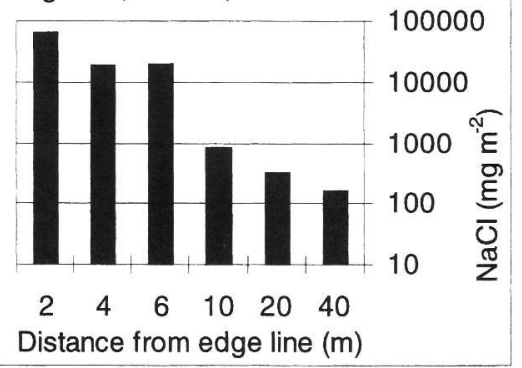

Fig. 4. Deposition pattern in Älgviken, week 1 and 2. Estimated precipitation week 1, 15-20 mm, week 2, 15-20 mm. Amount of salt applied on the road week $1,405 \mathrm{~g} \cdot \mathrm{m}^{-1}$; week $2,370 \mathrm{~g} \cdot \mathrm{m}^{-1}$.
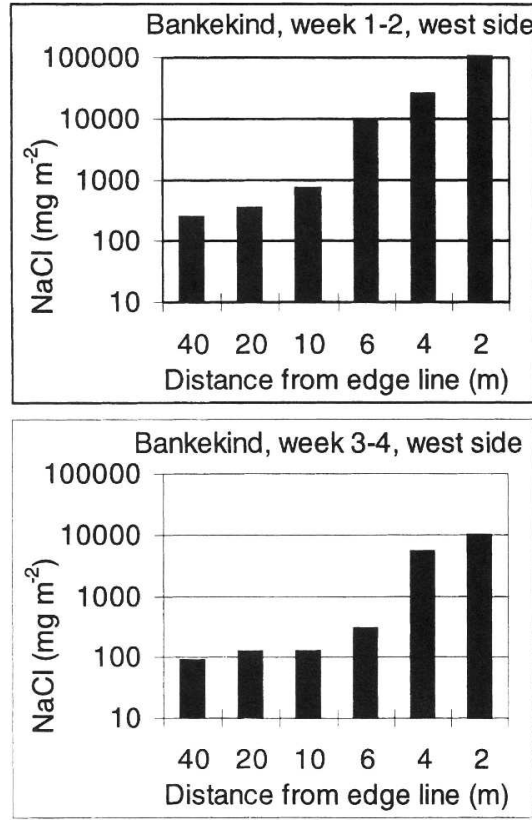

Bankekind, week 1-2, east side

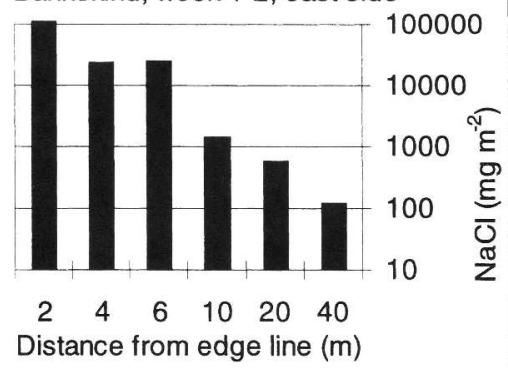

Distance from edge line $(\mathrm{m})$

Bankekind, week 3-4, east side

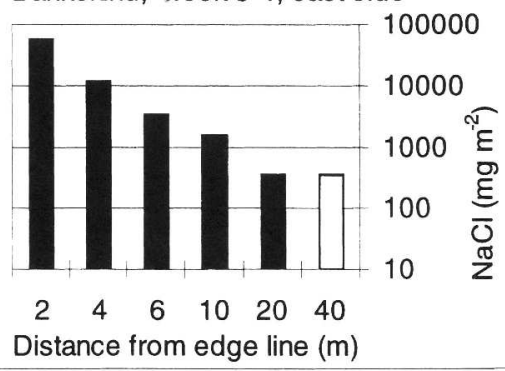

Fig. 5. Deposition pattern in Bankekind week 1-2 and 3-4. Estimated precipitation week 1-2, 25-30 mm; week 3-4, 7-10 mm. Amount of salt applied on the road week $1-2,1290 \mathrm{~g} \cdot \mathrm{m}^{-1}$; week $3-4,690 \mathrm{~g} \cdot \mathrm{m}^{-1}$. 
Table 1

Percentages of depositions and winds

\begin{tabular}{|c|c|c|c|c|c|c|c|c|}
\hline & \multicolumn{2}{|c|}{$\begin{array}{l}\text { Älgviken, } \\
\text { Week } 1\end{array}$} & \multicolumn{2}{|c|}{$\begin{array}{l}\text { Älgviken, } \\
\text { Week } 2\end{array}$} & \multicolumn{2}{|c|}{$\begin{array}{l}\text { Bankekind, } \\
\text { Week 1-2 }\end{array}$} & \multicolumn{2}{|c|}{$\begin{array}{l}\text { Bankekind, } \\
\text { Week 3-4 }\end{array}$} \\
\hline & W & $\mathrm{E}$ & $\mathrm{W}$ & $\mathrm{E}$ & W & $\bar{E}$ & $\overline{\mathrm{W}}$ & $\mathrm{E}$ \\
\hline $\begin{array}{l}\text { Percentage of collected salt deposited } \\
\text { on each side of the road }\end{array}$ & 32 & 68 & 26 & 74 & 44 & 56 & 19 & 81 \\
\hline $\begin{array}{l}\text { Percentage of collected salt deposited } \\
\text { within } 10 \mathrm{~m} \text { from edge line }\end{array}$ & 79 & 78 & 91 & 94 & 94 & 93 & 86 & 85 \\
\hline Winds from ${ }^{\mathrm{a}}$ & 61 & 39 & 100 & 0 & 45 & 55 & 95 & 5 \\
\hline Winds from ${ }^{\mathrm{a}}$, speed $>5 \mathrm{~ms}^{-1}$ & 78 & 22 & 100 & 0 & 98 & 2 & 100 & 0 \\
\hline $\begin{array}{l}\text { Percentage of salt applied, } \\
\text { deposited } 2-40 \mathrm{~m} \text { from edge line }\end{array}$ & 20 & & 63 & & 36 & & 26 & \\
\hline
\end{tabular}

${ }^{\mathrm{a}}$ Winds that are parallel to the road orientation are not included.

for the first $6 \mathrm{~h}$ following each de-icing operation. Only the winds not parallel to the road were taken into account.

The samples were stored for $1-3$ weeks prior to analysis. The water was filtered and samples of $100 \mathrm{ml}$ were stored cool for further analyses. Subsequently, the concentration of $\mathrm{Na}$ was measured with an ICP (Induced Coupled Plasma Emission) of the brand Jobin-Yvon and the Clconcentration was measured with a Dionex Dx-120 ion-chromatograph.

In order to calculate the total deposition the mean values were calculated from the double transects. Missing values (non-filled bars in Figs. 4 and 5) were interpolated by the geometric mean between the surrounding two values (Fig. 4) and by extrapolating the second last value to the outmost position (Fig. 5). The total amounts of sodium chloride deposited on both sides of the road were then integrated and the sum related to the amount of de-icing salt applied on the road.

\section{Results}

For all periods and both localities, the deposition was greater on the east side (Table 1).

During the first week at Älgviken (Fig. 4), 20\% of the total amount of salt applied on the road was deposited on the ground, 2-40 $\mathrm{m}$ from the

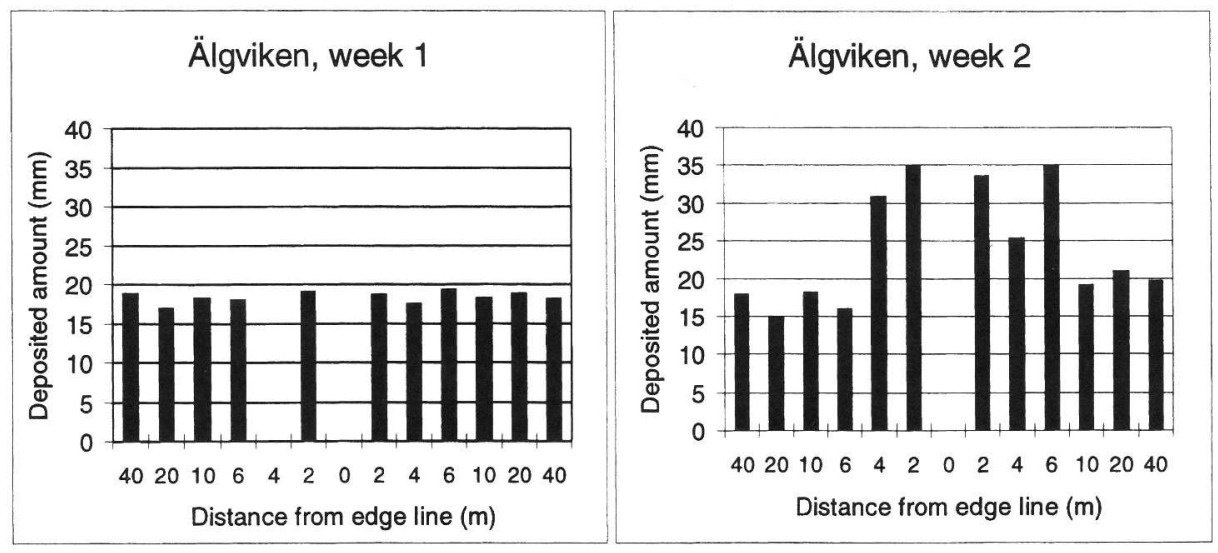

Fig. 6. Amount of deposition (mm) at Älgviken. 

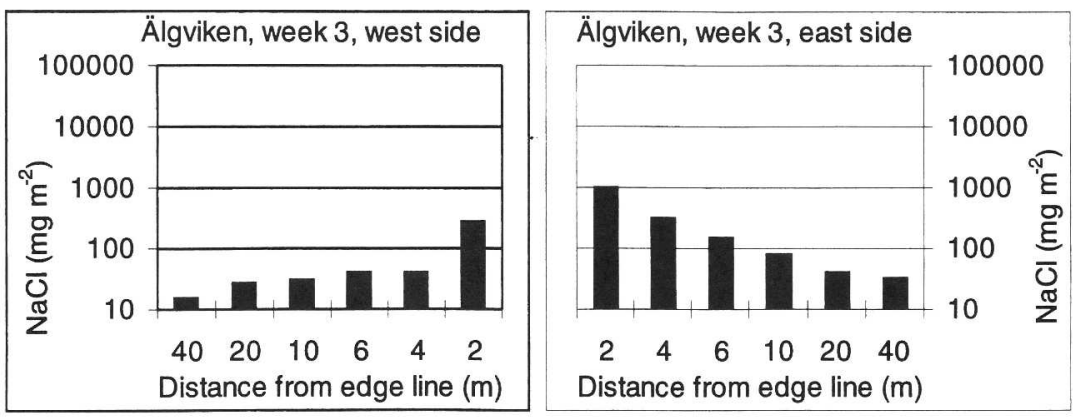

Fig. 7. Deposition pattern in Älgviken, week 3. Estimated precipitation week 3, 6-8 mm. No de-icing action took place.

edge of the road (Table 1). During the second week a much larger amount of deposition was found in the collectors close to the road (Fig. 6) and the total deposition was much greater $(63 \%)$. The deposition was also registered during a week when no de-icing action took place (Fig. 3). The amount of salt deposited on the ground was one order of magnitude lower (Fig. 7), but still considerable taking into account that no salt was applied on the road.

At Bankekind (Fig. 5) 36\% of the salt applied on the road was transported by air and deposited 2-40 $\mathrm{m}$ from the road the first 2-week period. (Table 1). During the second period less salt was deposited; $26 \%$ of the amount applied was deposited. In the $400-\mathrm{m}$ profile from Bankekind the deposition seems not to have levelled out at $40 \mathrm{~m}$ (Fig. 8).

When considering both localities and all periods, it is obvious that the major part of the

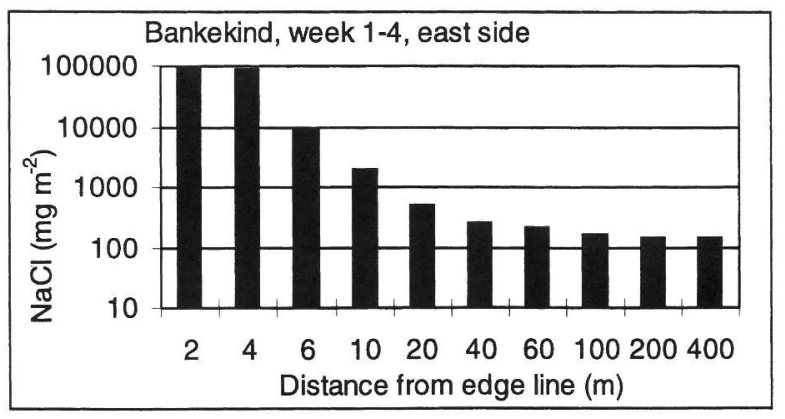

Fig. 8. Deposition pattern in Bankekind, week 1-4, long profile. Estimated precipitation week 1-4, 33-37 mm. Amount of salt applied on the road week $1-4,1980 \mathrm{~g} \cdot \mathrm{m}^{-1}$. deposition occurs within the first few metres from the edge line of the road (Fig. 9).

\section{Discussion}

Pedersen and Fostad (1996) showed that $10-25 \%$ of the applied salt was spread through the air. But since their result is calculated from deposition $2-16$ or $2-20 \mathrm{~m}$, and the salt probably is transported to greater distances, their result might be an underestimation. In this investigation $20-63 \%$ of the applied salt was spread through air and deposited 2-40 $\mathrm{m}$ from the edge line (Table 1). One reason for the higher percentages in this study is the longer profiles.

The reason for the high variation between the periods is that the transport mechanisms (Fig. 1) have different influence depending on the meteorological conditions during each period. The high percentages in Älgviken week $2(63 \%)$, and in Bankekind week 1-2 (36\%) is suggested to be due to a period of intense snowfall occurring in these two periods which lead to more splash generation and ploughing. This can also be seen in the amount of liquid deposited within the first metres in Älgviken week 2 as compared to Älgviken week 1 (Fig. 6). The high percentage of deposited salt during week 2 in Älgviken is coherent with Dragsted (1980) who found that the salt was transported a shorter distance during a period with many snowfalls than during a period with just wet road surface.

For all periods and both localities, the deposition was greater on the east side. When compar- 


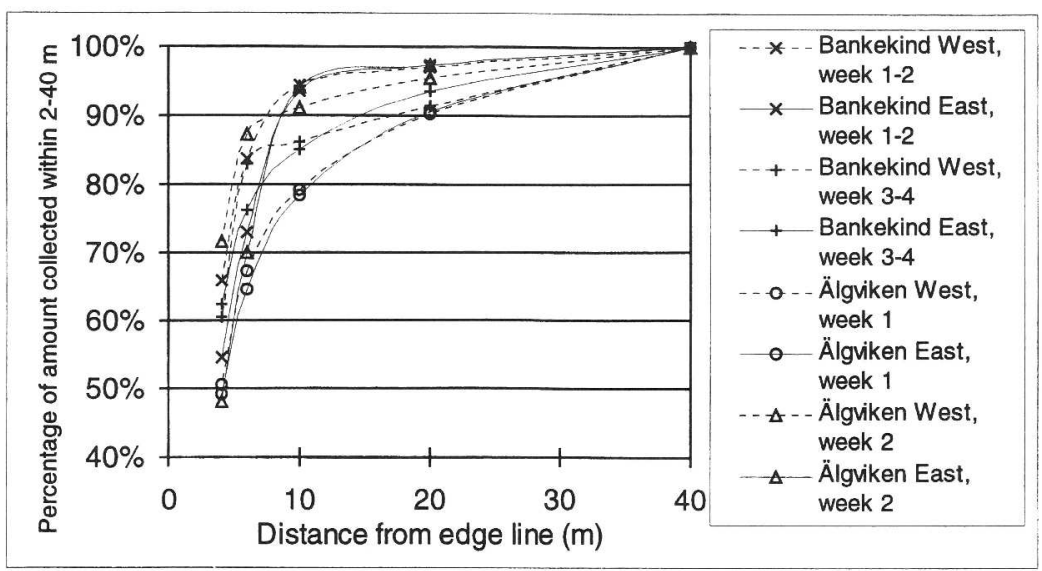

Fig. 9. Distribution of the relative amount of deposited $\mathrm{NaCl}$ at each transect and time period.

ing the periods; the deposition on the east side was greater during the second week in Älgviken which coincided with strong solely westerly winds (Table 1). In Bankekind the deposition was notably higher on the east side weeks 3-4 when there was a high percentage strong westerly winds compared to the first 1-2 weeks when there were more easterly than westerly winds, although the westerly winds were stronger (Table 1).

McBean and Al-Nassri (1987) concluded that $90 \%$ of the total amount of deposited salt was found within $13 \mathrm{~m}$. However, at roads with higher velocities ( 80 and $100 \mathrm{~km} \mathrm{~h}^{-1}$ ) no samples were taken 1-6 $\mathrm{m}$ from the edge of the road where most likely a large amount of deposition occurs. In our investigation $90 \%$ or more of the total deposition between 2 and $40 \mathrm{~m}$ has occurred within $20 \mathrm{~m}$ at all transects (Fig. 9).

Data from the nearest precipitation stations in the nationwide network, Aspvreten and Tyresta (Fig. 2), show that the depositions of $\mathrm{Na}$ and $\mathrm{Cl}$ vary considerably during February and March 1997 (Fig. 10). In the $400 \mathrm{~m}$ profile the deposition at $100 \mathrm{~m}$ seems to be in accordance with background values (Fig. 10), which means that some deposition has occurred between 40 and $100 \mathrm{~m}$. However, since there is no consistent background value for $\mathrm{NaCl}$-deposition, and since the con-

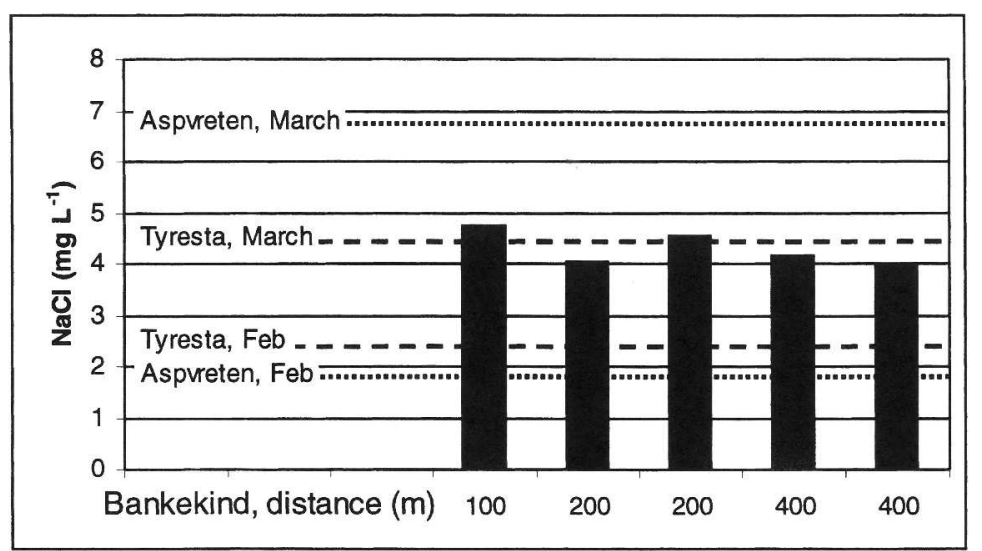

Fig. 10. NaCl-concentration in deposition 100-400 of the road at Bankekind as compared to regional background values for two precipitation stations (Aspvreten and Tyresta). 
tribution from background deposition is very small compared to the deposition resulting from road salt, no reduction for background deposition has been made in the calculations. The deposition between 40 and $100 \mathrm{~m}$ has been left out of account for the same reasons.

The high amount of deposition the third week in Älgviken is suggested to be a result of resuspension of road salt, which is considered to be of importance for the increase of atmospheric concentrations of $\mathrm{NaCl}$ during winter (Nicholson and Branson, 1990).

\section{Acknowledgements}

This project has been financed by the Swedish National Road Administration through the Centre for Research and Education in Operation and Maintenance of Infrastructure (CDU) at the Royal Institute of Technology (KTH) in Stockholm.

\section{References}

Bäckman L, Folkeson L. The influence of de-icing salt on vegetation, groundwater and soil along highways E20 and 48 in Skaraborg County during 1994 . VTI meddelande $\mathrm{Nr}$ 775A, 1995:45.

Bäckman L. Vintervägsaltets miljöpåverkan - Resultat av jord- och grundvattenprovtagningar vid observationsområden i Skaraborgs län 1994-1996. VTI Notat Nr 25, 1997 (in Swedish).

Dragsted J. Deicing salt and roadside trees, Vejdirektoratet, Denmark, Statens vejlaboratorium. Laboratorierapport 46, 1980:77 (in Danish, English abstract).

Eliasson $\AA$. Spridning av vägsalt kring vägar. Göteborgs Universitet: Projektarbete, Naturgeografiska Institutionen, 1996:34 (in Swedish).

Ericsson B. Projekt Restsalt. En sammanfattning av kunskapsläget. Delrapport, Vägverkets publ. 1995:62, 11 pp. (in Swedish).

Harrison RM, Johnston WR, Ralph JC, Wilson SJ. The budget of lead, copper and cadmium for a major highway. Sci Total Environ 1985;46:137-145.
Hautala E-L, Rekilä R, Tarhanen J, Ruuskanen J. Deposition of motor vehicle emissions and winter maintenance along roadside assessed by snow analyses. Environ Pollut 1995:87:45-49.

Hewitt CN, Rashed MB. An integrated budget for selected pollutants for major rural highway. Sci Total Environ 1990;93(1990):375-384.

Hofstra G, Hall R. Injury on roadside trees: leaf injury on pine and white cedar in relation to foliar levels of sodium and chloride. Can J Bot 1971;49:613-622.

Hofstra G, Hall R, Lumis GP. Studies of salt-induced damage to roadside plants in Ontario. J Arboricult 1979;5(2):25-31.

Jones PH, Jeffrey BA, Watler PK, Hutchon H. Environmental impact of road salting - state of the art. The Research and Development Branch, Ontario Ministry of Transportation and Communications, RR 237. 1986:53.

Karlqvist L. Vinteravfallet frăn väg och dess fixering i markprofilen, Kvartärgeologiska avdelningen. Uppsala Universitet: Forskningsrapport, Report 1974:11 (in Swedish).

Kelsey PD, Hootman RG. Deicing salt dispersion and effects on vegetation along highways, case study: deicing salt deposition on the Morton arboretum. In: D'Itri FM, editor. Chemical deicers and the environment. Chelsea, Michigan: Lewis, 1992:253-281.

McBean E, Al-Nassri S. Migration pattern of de-icing salts from roads. J Environ Manage 1987;25:231-238.

Nicholson KW, Branson JR. Factors affecting resuspension by road traffic. Sci Total Environ 1990;93:349-358.

Pedersen PA, Fostad O. Effects of deicing salt on soil, water and vegetation. Part I: Studies of soil and vegetation, MITRA nr. 01/96, Norges landbrukshøgskole, Institutt for Plantefag, 1996:65 (in Norwegian, English summary).

Persson AR, Røyseland J. Skader på omliggende grønnsakareal ved bruk av $\mathrm{NaCl}$ på vinterveg, Stenciltrykk nr. 36, Institutt for grønnsaksdyrking, Norges Landbrukshøgskole, As, ISBN 82-576-5596-1, 1981:29 (in Norwegian).

Pilon PE, Howard KWF. Contamination of subsurface waters by road de-icing chemicals. Water Pollut Res J Canada 1987;22(1):157-171.

Røhr PK. Effects of deicing salt on soil, water and vegetation. Part II: Examination of soil and effects of deicing salt in selected soil type areas, MITRA nr. 02/96, Norges landbrukshøgskole, Institutt for Plantefag, 1996:38 (in Norwegian, English summary).

Rutter AJ, Thompson JR. The salinity of motorway soils. III Simulation of the effects of salt usage and rainfall on sodium and chloride concentrations in the soil of central reserves. J Appl Ecol 1986;23:281-297.

Simini M, Leone IA. Studies on the effects of de-icing salts on roadside trees. Arboricult J 1986;10:221-231. 
VI FORSKAR FÖR ETT LIV I RÖRELSE

Statens väg- och transportforskningsinstitut (VTI) har kompetens och laboratorier för kvalificerade forskningsuppdrag inom transporter och samhällsekonomi, trafiksäkerhet, fordon, miljö samt för byggande, drift och underhăll av vägar och järnvägar.

The Swedish National Road and Transport Research Institute (VTI) has laboratories and know-how for advanced research commissions in transport and welfare economics, road safety, vehicles and the environment. It also has research capabilities for the construction, operation and maintenance of roads and railways.

\section{Adress}

Postal address

SE-581 95 Linköping, Sweden
Telefon

Telephone

Nat 013-20 4000

Int +4613204000
Fax

E-post

E-mail

Nat 013-14 1436

Int +4613141436 